\title{
Synopsis of the genus Exalphus Restello, Iannuzzi \& Marinoni (Coleoptera, Cerambycidae, Lamiinae), with description of a new species and new country records
}

\author{
Diego de Santana Souza ${ }^{1} \&$ Marcela Laura Monné ${ }^{2}$
}

\author{
${ }^{1}$ Departamento de Zoologia, Universidade Federal do Paraná, UFPR. Caixa Postal 19020, 81531-990 Curitiba-PR, Brazil. \\ diegosantanasouza@hotmail.com \\ ${ }^{2}$ Departamento de Entomologia, Museu Nacional, Universidade Federal do Rio de Janeiro, UFRJ. Quinta da Boa Vista, São Cristóvão, \\ 20940-040, Rio de Janeiro-RJ, Brazil.mlmonne2@gmail.com
}

\begin{abstract}
Synopsis of the genus Exalphus Restello, Iannuzzi \& Marinoni (Coleoptera, Cerambycidae, Lamiinae), with description of a new species and new country records. A synopsis of Exalphus Restello et al., 2001 is presented. Exalphus solangeae sp. nov. is described from Brazil (Amazonas). A key to identification with illustrations for 14 species of the genus is provided, and notes on distribution with new records are included for nine species: E. biannulatus (Aurivillius, 1921), E. calvifrons (Bates, 1872), E. colasi (Lane, 1965), E. foveatus (Marinoni \& Martins, 1978), E. gounellei (Lane, 1973), E. guaraniticus (Lane, 1955), E. leuconotus (Thomson, 1860), E. malleri (Lane, 1955) and E. spilonotus Restello, Iannuzzi \& Marinoni, 2001.
\end{abstract}

KEYWORDS. Acanthoderini; geographical distribution; Insecta; Neotropical Region; taxonomy.

Exalphus Restello, Iannuzzi \& Marinoni, 2001 is a genus of Lamiinae (Acanthoderini) with 15 species described from the Neotropical Region. This genus was initially proposed for 13 species previously placed in Alphus White, 1855, which differed mainly by: pronotum with transverse depression at anterior margin, elytra with basal-crests elevated, elytral punctation irregularly distributed, mesosternal process sloped on anterior half at angle of approximately 90 degrees with respect to mesosternum, and tarsomeres $\mathrm{V}$ bicolored. In the same work in which the genus was proposed, Restello et al. (2001) described two new species, E. confusus and E. spilonotus, both from Brazil.

The objective of this study was to describe a new species in Exalphus, to supply a key of identification for the 16 species of the genus, and to update the records of geographical distribution of the species.

We examined specimens from the following institutions: Coleção de Entomologia Pe. Jesus Santiago Moure, Departamento de Zoologia, Universidade Federal do Paraná, Curitiba, Paraná, Brazil (DZUP); Museu Nacional, Universidade Federal do Rio de Janeiro, Rio de Janeiro, Brazil (MNRJ); Museu de Zoologia, Universidade de São Paulo, São Paulo, Brazil (MZSP); and Coleção Entomológica, Departamento de Zoologia, Universidade Federal de Pernambuco, Recife, Pernambuco, Brazil (UFPE). The species E. simplex (Galileo \& Martins, 1998) and E. vicinus Galileo \& Martins, 2003 were examined by means of photographs of their respective holotypes. New distribution records are indicated by an asterisk.

In light of the publication of the "Catalogue of the Cerambycidae (Coleoptera) of the Neotropical Region. Part
I. Subfamily Cerambycinae" (Monné 2005), the references provided for each taxon are limited to the original description and papers published after 2005.

\section{Key for identification of the species of Exalphus}

1. Basal-crests elevated, with raised and aligned tubercles, united or separated from each other; humeri with at least one differentiated and well-developed tubercle at base of humeral carina; setae on femora not forming transverse bands

- Basal-crests corrugated or slightly elevated, without raised and aligned tubercles; humeri punctate, without raised tubercles; setae on femora forming transverse bands or not

2(1). Area with white setae on elytra with well-defined margins; femora mainly covered by dense white setae, with irregular spots of sparse setae.....

- Area with white setae on elytra fading toward margins; femora mainly covered by sparse setae, with dense spots of white setae forming well-defined transverse bands . 6

3(2). Lateral tubercles of pronotum with rounded base and apex slightly pronounced, not directed backward ......... 4

- Lateral tubercles of pronotum with non-rounded base and apex distinctly pronounced, directed backward ........... 5

4(3). Pronotum, between median tubercles, covered with white setae; basal-crests slightly raised; area with white setae on elytra extending to basal-crests (Fig. 1). Brazil (Bahia and Minas Gerais) .....

E. confusus Restello et al., 2001 
- Pronotum, between median tubercles, covered with brown setae; basal-crests only corrugated; area with white setae on elytra triangular, not extending to basal-crests (Fig. 2). French Guiana (Cayenne), Brazil (Maranhão, Mato Grosso, Bahia, Goiás, Minas Gerais and São Paulo) and Bolivia (Santa Cruz) ...... E. foveatus (Marinoni \& Martins, 1978)

5(3). Elytra mostly covered with brown setae, with faint spots of white setae irregularly distributed on dorsum. Ecuador (Napo and Pastaza)

E. simplex (Galileo \& Martins, 1998)

- Elytra with a dense area of white setae on dorsum, which starts near basal-crests and extends to apical fourth. Colombia (Santander)....

E. vicinus Galileo \& Martins, 2003

6(2). Pronotum with dense round macula of yellowish setae on median region; area with white setae on elytra fading toward scutellum and not reaching basal-crests (Fig. 3); mesosternum without lateral tubercles. French Guiana (Cayenne) and Brazil (Amazonas, Pará, Rondônia and Mato Grosso) ........... E. spilonotus- Restello et al., 2001

- Pronotum without round macula of yellowish setae on median region; area with white setae on elytra fading toward scutellum and reaching basal-crests (Fig. 4); mesosternum with lateral tubercles. Brazil (Amazonas)... E. solangeae sp. nov.

7(1). Basal-crests with undefined tubercles, united to each other (when separated, only the first one or two basal tubercles are separate)

- Basal-crests with well-defined tubercles, aligned and separated from each other

8(7). Pair of median tubercles of pronotum with apex subdivided in two tubercles; area with white setae on elytra densely covered and with well-defined lateral margins (Fig. $5)$; apical margin of elytra with a small spine on external apical angle. Peru (Ucayali and Junín), Brazil (Rondônia, Mato Grosso, Goiás, Bahia, Espírito Santo, São Paulo and Paraná), Bolivia (Beni, La Paz and Santa Cruz), Argentina (Misiones and Tucumán) and Paraguay (Itapúa and Guairá) E. gounellei (Lane, 1973)

- Pair of median tubercles of pronotum pyramidal, with rounded apex; area with white setae on elytra faintly covered and fading toward lateral margins; apical margin of elytra obliquely truncated.

9(8). Head with spot of white setae between upper ocular lobes; area with white setae on elytra extending approximately to apical third of epipleura (Fig. 6). French Guiana, Brazil (Amazonas, Pará, Rondônia and Mato Grosso), Ecuador, Peru (Junín) and Bolivia (Beni, Cochabamba and Santa Cruz) E. biannulatus (Aurivillius, 1921)

- Head uniformly covered with brownish setae between upper ocular lobes, without spots of white setae; area with white setae on elytra not extending to epipleura (Fig. 7). Guyana, French Guiana (Cayenne) and Brazil (Pará) .................. E. aurivillii (Lane, 1970)
10(7). Elytra with macula of dark-brown setae between basalcrests; elytral carinae slightly raised; humeral carina without tubercles.... 11

- Elytra without macula of dark-brown setae between basalcrests; elytral carinae raised; humeral carina with tubercles

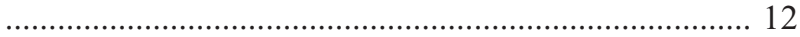

11(10). Prothorax and elytra with slight punctation and mostly covered with yellowish-white setae, with denser areas on base of lateral tubercles of prothorax and in median region of pronotum, and with irregularly distributed spots on elytra (Fig. 8). Brazil (Espírito Santo, Rio de Janeiro and São Paulo) ............................. E. zellibori (Lane, 1955)

- Prothorax and elytra with evident punctation and entirely covered with irregular spots of white, yellowish-white and brown setae, with denser areas of yellowish-white setae on base of lateral tubercles of prothorax and in median region of pronotum (Fig. 9). French Guiana and Brazil (Amazonas, Pará, Rondônia, Mato Grosso and Goiás) .. E. colasi (Lane, 1965)

12(10). Upper ocular lobes separated by two times their width; elytra with macula of dense and white setae on elytra, which starts near basal-crests and extends to apical fourth 13

- Upper ocular lobes separated by their width; elytra with irregular spots of white setae on elytra or with one lateral macula, not reaching elytral suture

13(12). Area with white setae on elytra with a narrow elongated notch at lateral margins (Fig. 10); ventral region of body covered with white setae. Brazil (Maranhão, Pernambuco, Bahia, Goiás, Minas Gerais, Espírito Santo, Rio de Janeiro, São Paulo, Paraná and Santa Catarina) and Argentina......

E. leuconotus (Thomson, 1860)

- Area with white setae on elytra with a wide rounded notch at lateral margins (Fig. 11); ventral region of body covered with yellow setae. Brazil (Rondônia and Mato Grosso), Bolivia (La Paz and Santa Cruz), Argentina (Salta and Formosa) and Paraguay (San Pedro)

E. guaraniticus (Lane, 1955)

14(12). Region between basal-crests with a row of three or four small tubercles parallel to crests; elytra mainly covered with brown setae, on each side with one macula of white setae surrounded by dark-brown setae, not reaching elytral suture (Fig. 12). Guyana and French Guiana

E. lichenophorus (Lane, 1965)

- Region between basal-crests without row of tubercles parallel to crests; elytra with maculae or spots of white setae reaching elytral suture 15

15(14). Scape without scar at outer surface of apex; elytra covered with brown setae, with irregular spot of white setae on apical third near elytral suture reaching to epipleura (Fig. 13). Venezuela (Amazonas), French Guiana (Cayenne), Ecuador, Brazil (Amazonas, Pará, Rondônia and Mato Grosso), Peru (Ucayali and Junín) and Bolivia (La Paz, Santa Cruz and Cochabamba) .............. E. malleri (Lane, 1955) 
- Scape with scar at outer surface of apex; elytra with faint white setae on basal half, also with irregular spots of dense white setae near elytral suture reaching to epipleura (Fig. 14). Guatemala, Honduras, Nicaragua (Chontales), Costa Rica, Panama (Chiriquí), Colombia (Valle del Cauca) and Ecuador ..... E. cavifrons (Bates, 1872)

\section{Exalphus solangeae sp. nov.}

(Fig. 4)

Description. Female. Integument dark brown. Body covered with dense short yellowish-gray setae. Head with fine and inconspicuous punctation; with coarse and sparse punctation between antennal tubercles and upper ocular lobes. Frons quadrangular, convex in lateral view; with frontal suture well-marked and prolonged to occiput; covered mostly with brown setae and whitish on posterior margin of lower ocular lobes. Upper ocular lobes almost one-third of lower ocular lobes; distance between them almost two times width of lobe. Lower ocular lobes rounded; height subequal to malar area. Genae convergent toward apex.

Antennae reaching elytral apex approximately at antennomere VIII; mostly covered with white setae. Scape without scar at outer surface of apex; covered with darkbrown setae and two spots of white setae, one in median region and another in ante-apical region. Pedicel with spot of dark-brown setae on outer surface of apex. Antennomeres III-V with spot of dark-brown setae in median region (gradually narrowing toward distal antennomeres) and one ring of dark-brown setae on apex; remaining antennomeres with ring of dark-brown setae in apical region, gradually widening toward distal antennomeres; antennomeres III and IV with sparse row of straight setae on inner surface.

Prothorax rectangular, about 1.7 times wider than long; lateral tubercles acute and directed backward. Pronotum with coarse and irregular punctation; covered with white setae, denser on lateral margins, forming a line which starts near lateral tubercles and continues diagonally toward basal-crests of elytra; with one pair of elevated median tubercles with glabrous apex; with slight elevation posterolaterally to median tubercles; with slight elevation covered with brown setae on midline, situated posterior to median tubercles. Width of prosternal process almost one-third the diameter of one procoxa; longitudinally depressed, blackish on lateral margins and posterior margin truncate, with projections to sides. Mesosternal process subequal in length to mesocoxa; lateral margins with pronounced tubercles and with one bend near tubercular projection of mesocoxa; posterior margin bilobed. Metasternum with one median longitudinal sulcus from posterior margin, not reaching anterior margin; anterior apex truncate; on each side, two transverse and parallel furrows near posterior margin.

Scutellum wider than long, subtriangular and with apical margin rounded; with one slight median longitudinal depression; covered with brown setae, with white setae on lateral extremities of base.
Elytra length about three times that of prothorax; with punctation gradually denser toward lateral margins; covered mainly with light brown setae and an "S"-shaped area with white setae on dorsum, growing fainter from base of elytra to apical third, surrounding scutellum and reaching basalcrests; margin of anterior half fading when compared with margin of posterior half, which is densely whitish and welldefined; apical third with one transverse line of irregular spots of brown setae that extends toward epipleura. Humeri rounded, without tubercles. Basal-crests slightly elevated, without defined tubercles, only with denser punctation. Elytral carinae slightly pronounced and without tubercles. Apical margin rounded.

Legs covered with sparse white setae. Femora and tibiae mainly covered with sparse setae, with denser areas of white setae forming well-defined transverse bands. Abdomen uniformly covered with sparse white setae. Sternite V wider than long; almost as long as length of sternites III and IV together.

Measurements (mm), female. Total length, 9.9; prothorax length, 2.3; prothorax maximum width, 3.4; elytral length, 6.4; humeral width, 3.9.

Etymology. This species is named after Dr. Dilma Solange Napp (DZUP), in recognition of her valuable support during the development of the master's study of the first author at the Universidade Federal do Paraná.

Type-material. Holotype, female, Brazil, Amazonas: Tabatinga, VIII.1978, B. Silva leg. (DZUP)

Discussion. Exalphus solangeae sp. nov. is similar to $E$. spilonotus in the general appearance of body and in the transverse bands of white setae on the femora and tibiae. The new species may be differentiated by the pronotum without a round macula of yellowish setae on median region, an area with white setae on the elytra fading toward the scutellum and reaching the basal-crests, and the mesosternum with lateral tubercles. Exalphus spilonotus has one dense round macula of yellowish setae in the median region of the pronotum, the area with white setae on the elytra is triangular in the apical half and fading toward the scutellum, not reaching the basalcrests, and the mesosternum lacks lateral tubercles.

\section{Exalphus biannulatus (Aurivillius, 1921)}

(Fig. 6)

Alphus biannulatus Aurivillius, 1921: 50.

Exalphus biannulatus; Restello et al., 2001: 296; Monné, 2005: 174 (catalogue); Wappes et al., 2006: 32 (checklist); Monné \& Hovore, 2006: 205 (checklist)

Geographical distribution. French Guiana, Brazil (Amazonas, Pará, Mato Grosso* and Rondônia), Ecuador, Peru (Junín) and Bolivia (Beni, Cochabamba and Santa Cruz).

Material examined. BRAZIL, Mato Grosso: Sinop, $12^{\circ} 31^{\prime} \mathrm{S}, 55^{\circ} 37^{\prime} \mathrm{W}$ (BR 163) Km 500 to 600, 7 females, X.1974; 1 male, 3 females, X.1975; 1 male, IX.1976, Roppa \& Alvarenga leg. (MNRJ); Vera, 1246'S 55³6’W, 1 female, X.1973, Alvarenga \& Roppa leg. (MNRJ). 


\section{Exalphus calvifrons (Bates, 1872)}

(Fig. 14)

Alphus cavifrons Bates, 1872: 206.

Exalphus cavifrons; Restello et al., 2001: 296; Monné, 2005: 174 (catalogue); Monné \& Hovore, 2006: 205 (checklist).

Alphus cavifrons Var. Bates, 1880: 136.

Alphus cavifrons var. batesi Aurivillius, 1923: 379.

Geographical distribution. Guatemala, Honduras, Nicaragua (Chontales), Costa Rica, Panama (Chiriquí), Colombia* (Valle del Cauca) and Ecuador.

Material examined. COLOMBIA, Valle del Cauca: Cali (1.35 mtrs.), 1 female, Dirings leg. (MZSP).

\section{Exalphus colasi (Lane, 1965)}

(Fig. 9)

Alphus colasi Lane, 1965: 305.

Exalphus colasi; Restello et al., 2001: 296; Monné, 2005: 174 (catalogue); Monné \& Hovore, 2006: 205 (checklist).

Geographical distribution. French Guiana and Brazil (Amazonas, Pará, Mato Grosso, Rondônia* and Goiás).

Material examined. BRAZIL, Rondônia: Ouro Preto do Oeste, 1 male, XII.1983, B. Silva leg. (MNRJ); 2 males, 2.XI.1987, C. Elias leg. (DZUP).

\section{Exalphus foveatus (Marinoni \& Martins, 1978)}

(Fig. 2)

Alphus foveatus Marinoni \& Martins, 1978: 178.

Exalphus foveatus; Restello et al., 2001: 296; Monné, 2005: 174 (catalogue); Wappes et al., 2006: 32 (checklist); Monné \& Hovore, 2006: 205 (checklist); Morvan \& Morati, 2006: 35 (distribution); Martins et al., 2009b: 516 (distribution); Giuglaris, 2012: 63 (distribution).

Geographical distribution. French Guiana (Cayenne), Brazil (Maranhão, Mato Grosso, Bahia, Goiás, Minas Gerais* and São Paulo) and Bolivia (Santa Cruz).

Material examined. BRAZIL, Minas Gerais: Águas Vermelhas (Curral de Dentro), XII.1972, Seabra \& Roppa leg. (MNRJ); Pedra Azul, 1 female, XII.1970, F. M. Oliveira leg. (MNRJ); 3 females, XI.1972, Seabra \& Oliveira leg. (MNRJ); Nova Lima, 1 female, XII.1992, R. Guimarães leg. (MNRJ).

\section{Exalphus gounellei (Lane, 1973)}

(Fig. 5)

Alphus gounellei Lane, 1973: 398.

Exalphus gounellei; Restello et al., 2001: 296; Monné, 2005: 174 (catalogue); Wappes et al., 2006: 32 (checklist); Monné \& Hovore, 2006: 205 (checklist); Demez \& Touroult, 2011: 104 (distribution).

Geographical distribution. Peru (Ucayali and Junín), Bolivia (Beni, La Paz* and Santa Cruz), Brazil (Mato Grosso, Rondônia*, Goiás, Bahia, Espírito Santo, São Paulo and Paraná), Argentina (Misiones and Tucumán) and Paraguay (Itapúa and Guairá).
Material examined. BOLIVIA, La Paz: Guanay, 1 female, X.1996 (MZSP). BRAZIL, Rondônia: Ouro Preto do Oeste, 1 male, XI.1983, Becker, Roppa \& Silva leg. (MNRJ); 2 females, X.1986, O. Roppa, P. Magno \& J. Becker leg. (MNRJ); 1 male, 18.X.1987, 1 female, 2.XI.1987, C. Elias leg. (DZUP); Pimenta Bueno, 1 male, X.1986, O. Roppa, P. Magno \& J. Becker leg. (MNRJ); 1 female, X.1986, O. Roppa, P. Magno \& J. Becker leg. (DZUP); Vilhena, 3 males, 8 females, X.1990, O. Roppa \& J. Becker leg. (MNRJ).

\section{Exalphus guaraniticus (Lane, 1955)}

(Fig. 11)

Alphus guaraniticus Lane, 1955: 292.

Exalphus guaraniticus; Restello et al., 2001: 298; Monné, 2005: 175 (catalogue); Wappes et al., 2006: 32 (checklist); Monné \& Hovore, 2006: 205 (checklist).

Geographical distribution. Brazil* (Rondônia and Mato Grosso), Bolivia (La Paz and Santa Cruz), Argentina (Salta and Formosa*) and Paraguay (San Pedro).

Material examined. BRAZIL, Rondônia: Ouro Preto do Oeste, 1 male, XI.1983, Roppa \& Silva leg. (MNRJ); Costa Marques (Forte Príncipe da Beira), 1 male, XI.1961, F. M. Oliveira leg. (MNRJ); 1 female, 10.XI.1961, F. M. Oliveira leg. (MNRJ); Mato Grosso: Diamantino (BR 163, Km 206), 1 female, X.1979, O. Roppa leg. (MNRJ); Pontes e Lacerda, 1 male, X.1988, O. Roppa, P. Magno \& J. Becker leg. (MNRJ). ARGENTINA, Formosa, 1 male, 15.X.1941, Foerster leg. (MNRJ).

\section{Exalphus leuconotus (Thomson, 1860)}

(Fig. 10)

Alphus leuconotus Thomson, 1860: 10.

Exalphus leuconotus; Restello et al., 2001: 298; Monné, 2005: 175 (catalogue); Monné \& Hovore, 2006: 205 (checklist); Martins et al., 2009a: 240 (distribution); Monné et al., 2012: 47 (distribution); Bezark, 2013: 48 (distribution)

Comments. Exalphus leuconotus is very similar to $E$. guaraniticus in the general appearance of the body and the coloration pattern of the dorsum. Some records of $E$. leuconotus exist from Brazil (Rondônia and Mato Grosso) and Bolivia (La Paz); however, all examined specimens that were identified as E. leuconotus from these localities actually correspond to E. guaraniticus. Therefore, here we opted to exclude the records of these three localities for this species.

Geographical distribution. Brazil (Maranhão, Pernambuco*, Bahia, Goiás*, Minas Gerais, Espírito Santo, Rio de Janeiro, São Paulo, Paraná and Santa Catarina) and Argentina.

Material examined. BRAZIL, Pernambuco: Tapira, 2 males, 5.XI.1929, P. B. Pivail? leg. (MZSP); Igarassu, Usi. S. José (Piedade), 1 male, 9.XI.2007, A. Maia leg. (UFPE); Goiás: Leopoldo de Bulhões, 1 male, XII.1933, R. Spitz leg. (MZSP).

\section{Exalphus malleri (Lane, 1955)}

(Fig. 13)

Alphus malleri Lane, 1955: 287.

Exalphus malleri; Restello et al., 2001: 298; Monné, 2005: 175 (catalogue); Wappes et al., 2006: 32 (checklist); Monné \& Hovore, 2006: 

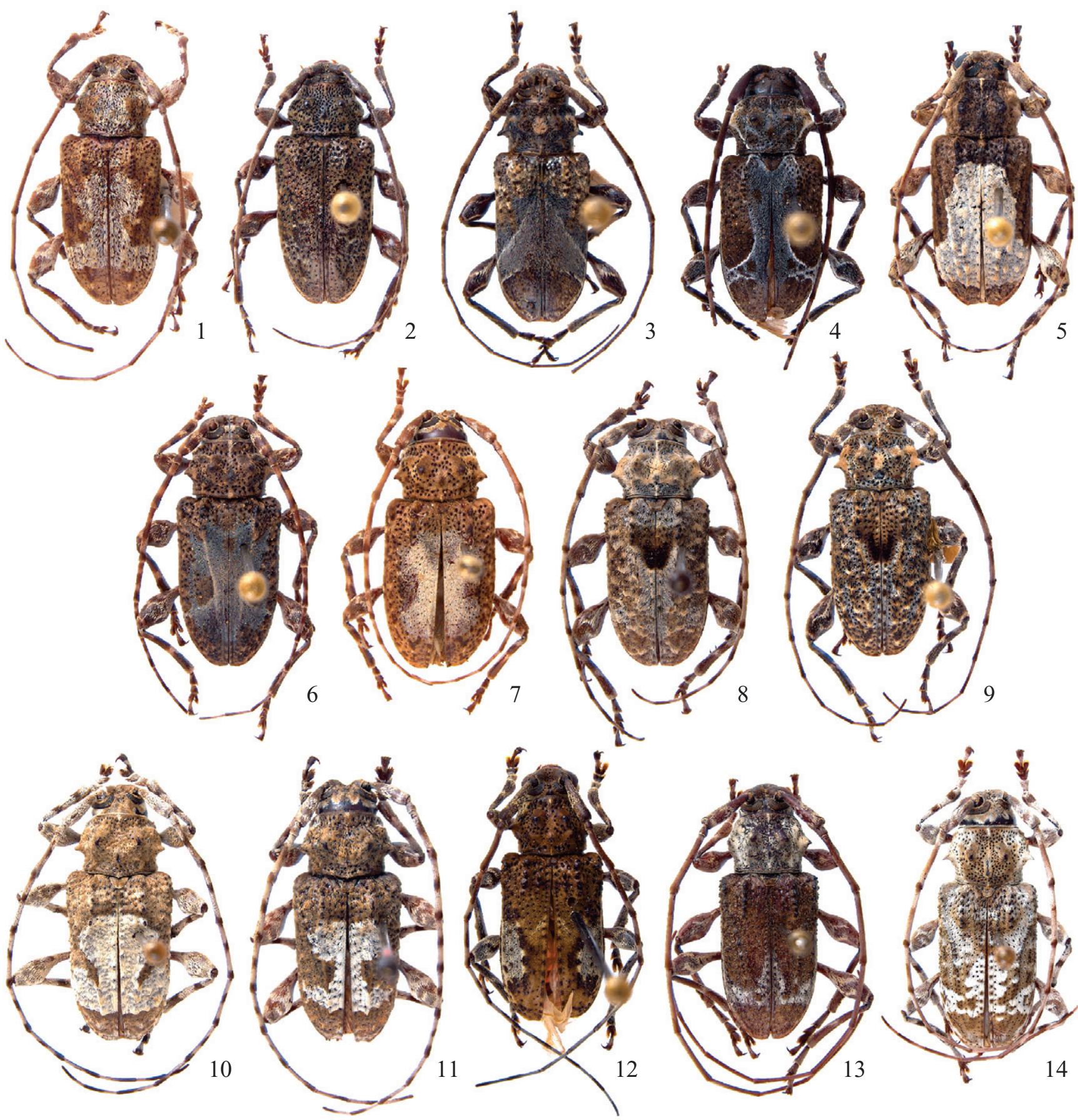

Figs. 1-14. 1-9. 1, Exalphus confusus Restello, Iannuzzi \& Marinoni, 2001, male; 2, Exalphus foveatus (Marinoni \& Martins, 1978), male; 3, Exalphus spilonotus Restello, Iannuzzi \& Marinoni, 2001, male; 4, Exalphus solangeae sp. nov., holotype, female; 5, Exalphus gounellei (Lane, 1973), male; 6, Exalphus biannulatus (Aurivillius, 1921), male; 7, Exalphus aurivillii (Lane, 1970), male; 8, Exalphus zellibori (Lane, 1955), male; 9, Exalphus colasi (Lane, 1965), male. 10-14. 10, Exalphus leuconotus (Thomson, 1860), male; 11, Exalphus guaraniticus (Lane, 1955), male; 12, Exalphus lichenophorus (Lane, 1965), male; 13, Exalphus malleri (Lane, 1955), male; 14, Exalphus cavifrons (Bates, 1872), male.

205 (checklist); Morvan \& Morati, 2006: 36 (distribution); Touroult et al., 2010: 31 (distribution); Giuglaris, 2012: 63 (distribution).

Geographical distribution. Venezuela* (Amazonas), French Guiana (Cayenne), Ecuador, Brazil (Amazonas*, Pará, Rondônia and Mato Grosso), Peru (Ucayali* and Junín) and Bolivia (La Paz*, Santa Cruz and Cochabamba*).
Material examined. VENEZUELA, Amazonas: Alto Orinoco, 1 male, VI.1983 (MNRJ). BRAZIL, Amazonas: Manaus, 1 male, IV.1957, C. Elias leg. (DZUP); 2 males, X.1957, C. Elias leg. (DZUP); 1 male, 2 females, 7.XI.1957; 1 male, 29.XI.1957, Elias \& Roppa leg. (MNRJ); 2 males, II.1958, C. Elias leg. (DZUP); 1 male, VIII.1958, C. Elias leg. (DZUP); 5 males, 1 female, III.1959; 2 males, IV.1959, C. Elias leg. (MNRJ); 1 male, X.1959, C. Elias leg. (DZUP); 1 male, X.1961, M. Melo leg. (MNRJ); Manaus (Est. AMI, Km 30), 1 male, XI.1967, S. A. F. leg. (MNRJ); Ben- 
jamin Constant, 1 female, V.1956; 1 male, 2 females, VI.1956, I. C. Lima leg. (MNRJ); 1 male, VI.1957, I. C. Lima leg. (MNRJ); Benjamin Constant (Rio Javari), 1 male, II.1961, Dirings leg. (MZSP); Tabatinga, 1 male, X.1958, F. M. Oliveira leg. (MNRJ). PERU, Ucayali: Pucallpa, 1 male, 15.IX.1976 (MZSP). BOLIVIA, La Paz: Guanay, 1 male, XI.1982 (MZSP); Cochabamba: Chapare, 2 males, XI.1951 (DZUP); 1 female, 4.VI.1948, H. Zellibor leg. (MNRJ); 2 males, 25.III.1952, H. Zellibor leg. (MNRJ); "Region Chapare", 1 female, 1.X.1958, Zischka leg. (MNRJ)

\section{Exalphus spilonotus Restello, Iannuzzi \& Marinoni, 2001} (Fig. 3)

Exalphus spilonotus Restello et al., 2001; Monné, 2005: 175 (catalogue); Monné \& Hovore, 2006: 205 (checklist); Giuglaris, 2012: 63 (distribution).

Geographical distribution. French Guiana (Cayenne) and Brazil (Amazonas*, Pará, Rondônia and Mato Grosso).

Material examined. BRAZIL, Amazonas: Manaus, Reserva Ducke (AM 010, Km 26), 1 male, 8.VIII.1978 (MZSP).

\section{ACKNOWLEDGMENTS}

We are grateful to Dr. Miguel A. Monné (MNRJ) and Dr. Ubirajara Ribeiro Martins (MZSP) for the loan of specimens; to Dr. Luciane Marinoni (DZUP) for her support for the accomplishment of this study; to Dr. Janet W. Reid for reviewing the English text; to the Conselho Nacional de Desenvolvimento Científico e Tecnológico (CNPq) for the research grant (proc. 132932/2011-3) and to the Fundação Carlos Chagas Filho de Amparo à Pesquisa do Estado do Rio de Janeiro (FAPERJ) for grant E-26/103.263/2011.

\section{REFERENCES}

Aurivillius, C. 1921. Neue Cerambyciden aus der Sammlung G. van Roon. Tijdschrift voor Entomologie 64: 46-53.

Aurivillius, C. 1923. Coleopterorum Catalogus, pars 74. Cerambycidae: Lamiinae. Berlin, W. Junk, 323-704 p.

Bates, H.W. 1872. On the longicorn Coleoptera of Chontales, Nicaragua. Transactions of the Entomological Society of London 20: 163-238.

Bates, H.W. 1880. Biologia Centrali-Americana, vol. 5. Insecta, Coleoptera, Lamiidae. London, 17-152 p.

Bezark, L.G. 2013. Distributional records and updates to type repositories for some New World Cerambycidae (Coleoptera, Cerambycidae). Les Cahiers Magellanes 11: 39-58.
Demez, P. \& Touroult, J. 2011. Contribution à la connaissance des longicornes du Pérou I. 59 nouveaux signalements pour le pays (Coleoptera, Cerambycidae). Les Cahiers Magellanes 6: 97-108.

Giuglaris, J.L. 2012. Les longicornes en zone littorale de Guyane: échantillonnage de la zone agricole Wayabo de Matiti (Coleoptera, Cerambycidae) Contribution à l'étude des Coléoptères de Guyane Tome VI. Supplément au Bulletin de Liaison d'ACOREP - France "Le Coléopteriste" 6: 53-65.

Lane, F. 1955. Cerambycoidea Neotropica nova III (Coleoptera). Papéis Avulsos do Departamento de Zoologia 12: 281-296.

Lane, F. 1965. Cerambycoidea Neotropica nova VI (Coleoptera). Studia Entomologica 8: 269-336.

Lane, F. 1973. Cerambycoidea Neotropica nova IX (Coleoptera). Studia Entomologica 16: 371-438.

Marinoni, R.C. \& Martins, U.R. 1978. Notas sinonímicas e novas espécies em Acanthoderini (Coleoptera, Cerambycidae, Lamiinae). Papéis Avulsos de Zoologia 31: 173-193.

Martins, U.R., Galileo, M.H.M. \& Limeira-de-Oliveira, F. 2009a. Cerambycidae (Coleoptera) do estado do Maranhão, Brasil. Papéis Avulsos de Zoologia 49: 229-247.

Martins, U.R., Galileo, M.H.M. \& Limeira-de-Oliveira, F. 2009 b. Cerambycidae (Coleoptera) do estado do Maranhão, Brasil. II. Papéis Avulsos de Zoologia 49: 503-527.

Monné, M.A. \& Hovore, F. 2006. Checklist of the Cerambycidae, or longhorned wood-boring beetles, of the Western Hemisphere. Rancho Dominguez, BioQuip Publications, 393 p.

Monné, M.A. 2005. Catalogue of the Cerambycidae (Coleoptera) of the Neotropical Region. Part II. Subfamily Lamiinae. Zootaxa 1023: 1759

Monné, M.A., Nearns, E.H., Carril, S.C.C., Swift, I.P. \& Monné, M.L. 2012. Preliminary checklist of the Cerambycidae, Disteniidae, and Vesperidae (Coleoptera) of Peru. Insecta Mundi 0213: 1-48.

Morvan, O. \& Morati, J. 2006. Contribution à la connaissance des Cerambycidae de la Montagne de Kaw, Guyane Française (Coleoptera). Supplément 2. Lambillionea 106: 3-63.

Restello, R.M., Iannuzzi, L. \& Marinoni, R.C. 2001. Descrição de dois novos gêneros afins a Alphus White e duas novas espécies (Cerambycidae, Lamiinae, Acanthoderini). Revista Brasileira de Entomologia 45: 295-303.

Thomson, J. 1860. Essai d'une classification de la famille des cérambycides et matériaux pour servir a une monographie de cette famille. Paris, Bouchard-Huzard, $404 \mathrm{p}$.

Touroult, J., Dalens, P.-H., Brûlé, S. \& Poirier, E. 2010. Inventaire des longicornes: analyse de l'efficacité des techniques de collecte en Guyane (Coleoptera, Cerambycidae). Contribution à l'étude des Coléoptères de Guyane. Tome 1. Supplément au Bulletin de Liaison de l'ACOREP - France "Le Coléoptèriste", 15-33 p.

Wappes, J.E., Morris, R.F., Nearns, E.H. \& Thomas, M.C. 2006. Preliminary checklist of Bolivian Cerambycidae (Coleoptera). Insecta Mundi 20: 1-45.

White, A. 1855. Catalogue of the coleopterous insects in the collection of the British Museum, part 3. Longicornia 2. London, 175-412 p. 